\title{
Studi Jenis Media Pembibitan terhadap Pertumbuhan Bibit Mentimun (Cucumis sativus L.)
}

\author{
(Study of Seedling Media on The Growth of Cucumber (Cucumis sativus L.)) \\ Paramyta Nila Permanasari ${ }^{*}$, dan Anas Dinurrohman Susila ${ }^{2}$ \\ ${ }^{1}$ Jurusan Budidaya Pertanian, Fakultas Pertanian, Universitas Brawijaya, Jl. Veteran, Kota Malang \\ ${ }^{2}$ Departemen Agronomi dan Hortikultura, Fakultas Pertanian, Institut Pertanian Bogor \\ *Email korespondensi: diazpribadiparamyta@gmail.com
}

Diterima 21 September 2018/Disetujui 11 November 2018

\begin{abstract}
Cucumber is one of the Cucurbitaceae family that has important economic value. Qualified seeds is a sturdy seedlings, leafy green, healthy and have a good rooting. The purpose of this research was to know the appropriate media composition for the growth of cucumber seedlings. This research was held in Dramaga Bogor on 2013. The experiment was arranged in a completely randomized design with four replications and seven treatments. The treatment were vermicompost, husk charcoal, organic fertilizer granules, vermicompost-husk charcoal, vermicompost-organic fertilizer granules, husk charcoal-organic fertilizer granules, vermicompost-charcoal husk-organic fertilizer granules. The results showed that all the characters of observation (seed germination, plant height, leaf number, leaf area, root length, root volume, root and shoot ratio) were significantly different. The highest shoot fresh weight was obtained from the medium vermicompost-husk charcoal (25.16 g), followed by vermicompost (24.70 g), vermicompost-husk charcoal, organic fertilizer granules (16.60 g), husk charcoal (12.28 g), husk charcoal- organic fertilizer granules $(7.47 \mathrm{~g})$, vermicompost-organic fertilizer granules $(2.04 \mathrm{~g})$ and organic fertilizer granules $(0 \mathrm{~g})$. While the highest root fresh weight was obtained from the medium vermicompost-husk charcoal (2.72 g), followed by vermicompost-husk charcoal (2.43 $\mathrm{g})$, vermicompost $(2.43 \mathrm{~g})$, husk charcoal (1.37 g), vermicompost-organic fertilizer granules (1.07 g), husk charcoal-organic fertilizer granule $(0.23 \mathrm{~g})$, and organic fertilizer granules $(0 \mathrm{~g})$. In general it can be seen that the medium of cucumber seedling will give good growth if we use vermicompost as the major or partial component.
\end{abstract}

Keywords: cucumber transplant, husk charcoal, vermicompost.

ABSTRAK

Mentimun adalah salah satu keluarga Cucurbitaceae yang memiliki nilai ekonomi penting. Bibit berkualitas adalah bibit yang kuat, berdaun hijau, sehat dan memiliki perakaran yang baik. Tujuan penelitian ini adalah untuk mengetahui komposisi media yang tepat untuk pertumbuhan bibit mentimun. Penelitian ini dilaksanakan di Dramaga Bogor pada tahun 2013. Percobaan disusun dalam Rancangan Acak Kelompok dengan empat ulangan dan tujuh perlakuan. Perlakuan yang diberikan adalah vermikompos, arang sekam, pupuk organik granul, vermikompos-arang sekam, vermikompos-pupuk organik granul, arang sekampupuk organik granul, vermikompos- arang sekam- pupuk organik granul. Hasil penelitian menunjukkan bahwa semua karakter pengamatan (perkecambahan biji, tinggi tanaman, jumlah daun, luas daun, panjang akar, volume akar, rasio tajuk akar) berbeda nyata. Bobot basah tajuk tertinggi diperoleh dari vermikompos-arang sekam (25.16 g), diikuti oleh vermikompos (24.70 g), vermikompos - arang sekam- pupuk organik granul(16.60 g), arang sekam (12.28 g), arang sekam- butiran pupuk organik (7.47 g), vermikompos- pupuk organik granul (2.04 g) dan pupuk organikgranul (0 g). Sedangkan bobot basah akar tertinggi diperoleh dari vermikompos-arang sekam-pupuk organik granul( $2.72 \mathrm{~g})$, diikuti oleh arang sekam-vermikompos (2.43 g), vermikompos (2.43 g), arang sekam (1.37 g), vermikompos-pupuk organik granul (1.07 g), arang sekam - pupuk organik granul (0.23 g), dan pupuk organik granul $(0 \mathrm{~g})$. Secara umum dapat dilihat bahwa media pembibitan mentimun akan memberikan pertumbuhan yang baik jika kita menggunakan vermikompos sebagai komponen utama atau campuran.

Kata kunci: transplanting mentimun, arang sekam, vermikompos. 


\section{PENDAHULUAN}

Pembibitan sayuran merupakan langkah potensial yang dapat dikembangkan petani dalam menjalankan bisnis pertanian. Penanaman sayuran dalam bentuk bibit, bukan benih, lebih dapat menjamin kelangsungan hidup sayuran tanpa harus menunggu bibit yang tumbuh dari penanaman benih (direct seedling) serta dapat mengurangi biaya untuk penjarangan.

Mentimun (Cucumis sativus L.) merupakan salah satu famili Cucurbitacae yang memiliki nilai penting secara ekonomi. Mentimun sering dijual dalam bentuk acar ataupun sayuran segar (Mohiuddin et al., 2005). Penanaman mentimun dapat dilakukan secara langsung menggunakan benih atau menggunakan bibit yang telah siap pindah tanam.

Bibit yang berkualitas adalah bibit kekar, daunnya hijau, sehat, serta memiliki perakaran yang baik. Bibit mentimun yang sudah siap dipindah ke lapang adalah bibit yang berdaun 3-4 helai atau berusia 12-20 hari (Susila, 2006; Munir, 2011). Untuk menciptakan bibit sayuran yang memenuhi persyaratan tersebut, maka salah satu hal yang harus diperhatikan dalam pembibitan sayuran adalah media tanam.

Media tanam seharusnya memiliki sifat fisik dan kimia yang sesuai bagi pertumbuhan tanamman. Media yang baik memiliki daya pegang air, drainase, daya serap unsur hara, $\mathrm{pH}$, dan salinitas yang sesuai bagi pertumbuhan tanaman (Nair and Ngouajio, 2012). Media pembibitan yang sesuai untuk mentimun memiliki pH 5.5-6.8 (Santos, 2010) dan EC (electric conductivity) 1-1.5 millimhos $\mathrm{cm}^{-1}$ (Mirza and Younus, 2002). Contoh media yang digunakan pada pembibitan mentimun adalah sekam, arang sekam, serabut kelapa, dan arang kulit kacang dengan pertumbuhan bibit terbaik adalah di media arang kulit kacang. Media arang sekam dan serabut kelapa digolongkan sebagai media dengan daya pegang air yang besar (> $45 \% \mathrm{vv}^{-1}$ ) dan sebaliknya untuk media yang lain (Chulaka et al., 2004).

Penelitian ini bertujuan untuk mengetahui komposisi media pembibitan yang paling sesuai bagi pertumbuhan bibit mentimun.

\section{METODE PENELITIAN}

Penelitian dilaksanakan di Dramaga Bogor pada tahun 2013. Bahan yang digunakan adalah benih mentimun varietas Daria, vermikompos kotoran sapi, arang sekam, pupuk organik granul, tray 128, dan pupuk Gandasil-D. Peralatan yang digunakan adalah handsprayer dan alat budidaya lainnya.

Rancangan percobaan dan lingkungan yang digunakan adalah Rancangan Acak Kelompok satu faktor yaitu komposisi media. Terdapat tujuh perlakuan dengan empat ulangan. Satu ulangan terdiri dari 16 tanaman dengan 10 tanaman sebagai sampel. Sehingga total satuan percobaan adalah 448 tanaman. Perlakuan media meliputi:

M0: vermikompos (100\%)

M1: arang sekam (100\%)

M2: pupuk organik granul $(100 \%)$

M3: vermikompos (50\%) : arang sekam (50\%)

M4: vermikompos (50\%) : pupuk organik granul $(50 \%)$

M5: arang sekam $(50 \%)$ : pupuk organik granul $(50 \%)$

M6: vermikompos (33.3\%) : arang sekam (33.3\%) : pupuk organik granul $(33.3 \%)$

Benih timun terlebih dahulu diletakkan pada tisu basah di tempat tertutup dan dibiarkan selama 12 jam. Benih yang berkecambah kemudian ditanam di tray dengan satu benih per lubang. Pemeliharaan tanaman dilakukan dengan penyiraman, pemupukan, dan pembuangan bagian tanaman yang terserang hama atau patogen. Penyiraman dilakukan setiap hari pada waktu pagi hari. Pemupukan diberikan dengan konsentrasi $1 \mathrm{~g} \mathrm{~L}^{-1}$ setiap empat hari sekali.

Data bulk density, total pore space, $\mathrm{pH}$, dan $\mathrm{EC}$ media diukur sebelum penanaman. Data pertumbuhan seperti tinggi tanaman dan jumlah daun diamati setiap minggu kecuali daya berkecambah, hanya pada satu minggu setelah tanam. Luas daun diamati saat daun sempurna telah muncul hingga sebelum panen. Sementara data panjang akar, volume akar, bobot basah tajuk, bobot basah akar, dan rasio tajuk akar diamati saat panen. Data diolah menggunakan SAS dan data yang berbeda nyata diuji lanjut menggunakan Duncan Multiple Range Test (DMRT) dengan taraf kesalahan $5 \%$.

\section{HASIL DAN PEMBAHASAN}

\section{Sifat Fisik dan Kimia Media Tanam}

Sifat fisik dan kimia adalah karakter media tanam yang perlu diperhatikan. Media tanam yang baik harus mampu memberikan support fisik, menyuplai oksigen, menyuplai air, dan menyuplai nutrisi tanaman serta dapat mempertahankan wadah tanam berdiri tegak. Sifat fisik dan kimia beberapa komposisi media tanam yang digunakan pada pembibitan mentimun tertera pada Tabel 1 .

Media tanam terdiri dari bagian padat (solid) dan pori(makro-mikro). Bulk density adalah massa dari volume tertentu media kering (massa dari bagian padat dan total pore space). Bulk density bahan organik sekitar $0.5 \mathrm{~g}$ $\mathrm{ml}^{-1}$ (Agrilnfo, 2011). Komposisi media pada penelitian yang nilai bulk density nya mendekati $0.5 \mathrm{~g} \mathrm{ml}^{-1}$ adalah arang sekam-pupuk organik granul, pupuk organik granul, dan vermikompos. Bulk density mempengaruhi sifat fisik media yang menentukan kemudahan pergerakan akar dan kandungan air media. Media dengan bulk density rendah biasanya memilki sifat fisik yang baik (Agrilnfo, 2011). Media pembibitan mentimun yang memilliki bulk density terendah adalah arang sekam.

Total pore space merupakan salah satu faktor yang mempengaruhi bulk density. Total pore space terdiri dari pori mikro (terisi air) dan pori makro (terisi udara). Total pore space media dipengaruhi oleh bahan organik, struktur, dan tekstur. Semakin banyak kandungan bahan organik pada media, maka total pore space juga akan semakin meningkat dan nilai bulk density nya rendah (Agrilnfo, 2011). Pada komposisi media yang digunakan pada penelitian ini juga menunjukkan bahwa dengan semakin kecil nilai bulk density, maka total pore spacenya semakin besar. Arang sekam memiliki nilai bulk density terendah $\left(0.18 \mathrm{~g} \mathrm{~m}^{-1}\right)$ dan total pore space tertinggi (98.383\%). Media yang padat akan memiliki sedikit ruang pori.

Kesesuaian media tanam dipengaruhi oleh jenis tanaman yang diusahakan. Media pembibitan yang sesuai untuk mentimun memiliki $\mathrm{pH}$ 5.5-6.8 (Santos, 2010). Komposisi media tanam pada praktikum yang mendekati persyaratan $\mathrm{pH}$ tersebut adalah vermikompos dan arang sekamvermikompos. Kemasaman media sangat berpengaruh terhadap ketersediaan hara, aktivitas jasad renik, dan reaksi pupuk yang diberikan. Pada $\mathrm{pH}$ rendah biasanya terjadi toksisitas unsur hara mikro seperti besi, aluminium, dan mangan. Sebaliknya pada $\mathrm{pH}$ terlalu tinggi dapat terjadi defisiensi unsur mikro. 
Tabel 1. Sifat fisik dan kimia media tanam

\begin{tabular}{lcccc}
\hline \multicolumn{1}{c}{ Perlakuan Media } & BulkDensity $\left(\mathrm{g} \mathrm{ml}^{-1}\right)$ & Total Pore Space $(\%)$ & $\mathrm{pH}$ & Salinitas $\left.(\mathrm{Ms} \mathrm{cm})^{-1}\right)$ \\
\hline Vermikompos & 0.60 & $98.368 \mathrm{f}$ & 6.66 & 345 \\
Arang sekam & 0.18 & $98.383 \mathrm{a}$ & 8.10 & 206 \\
POG & 0.55 & $98.370 \mathrm{e}$ & 8.68 & 937 \\
Vermikompos: Arang sekam & 0.32 & $98.378 \mathrm{~b}$ & 6.91 & 260 \\
Vermikompos: POG & 0.73 & $98.363 \mathrm{~g}$ & 8.28 & 846 \\
Arang sekam: POG & 0.48 & $98.372 \mathrm{~d}$ & 8.20 & 318 \\
Vermikompos : Arang sekam:POG & 0.41 & $98.375 \mathrm{c}$ & 8.14 & 657
\end{tabular}

Keterangan: Angka pada kolom yang sama yang diikuti oleh huruf yang berbeda menunjukkan berbeda nyata pada taraf $5 \%$ ujiDMRT

Nilai EC dapat menunjukkan tingkat salinitas. Semakin banyak hara terlarut maka akan semakin tinggi juga kemampuan menghantarkan listrik (EC). Batasan nilai EC dimaksudkan untuk menghindari terjadinya penurunan penyerapan hara karena tanaman mulai jenuh menyerap hara. EC (electric conductivity) yang sesuai untuk pembibitan mentimun berkisar 1-1.5 millimhos $\mathrm{cm}^{-1}$ dan apabila tanaman sudah dipindahkan ke wadah yang lebih besar, EC maksimal yang masih dapat ditoleransi berkisar 3-4 millimho $\mathrm{cm}^{-1}$ (Mirza and Younus, 2002; Roddy, 2005). 1 millimhos $\mathrm{cm}^{-1}$ setara dengan $100000 \mu \mathrm{Scm}^{-1}$. Sebab $1 \mathrm{Sm}^{-1}=0.1 \mathrm{mmho} \mathrm{cm}^{-1}, 1 \mathrm{~S} \mathrm{~m}^{-1}=0.01 \mathrm{~S} \mathrm{~cm}^{-1}, 1 \mathrm{~S}$ $\mathrm{cm}^{-1}=1000 \mathrm{mS} \mathrm{cm}^{-1}=10^{6} \mu \mathrm{S} \mathrm{cm}^{-1}$. Sehingga semua komposisi media tanam yang digunakan pada pembibitan mentimun di penelitian ini masih dalam batas toleransi.

\section{Daya Berkecambah $(\%)$}

Daya berkecambah benih mentimun tertinggi ditunjukkan pada media pembibitan vermikompos, arang sekam, arang sekam-vermikompos, vermikompos-pupuk organik granul, dan vermikompos-arang sekam-pupuk organik granul (Tabel 2.). Secara garis besar dapat diketahui bahwa perkecambahan benih mentimun yang optimal berada pada media pembibitan yang komposisinya terdapat vermikompos atau arang sekam.
Namun media vermikompos terlihat lebih berperan positif, sebab campuran arang sekam- pupuk organik granul menunjukkan perkecambahan benih yang lebih rendah dibandingkan vermikompos-pupuk organik granul.

Vermikompos merupakan kompos yang berasal dari hasil perombakan bahan organik oleh cacing tanah. Vermikompos merupakan media pembibitan mentimun yang memberikan pertumbuhan kecambah yang optimal. Vermikompos mengandung hormon yang dapat memacu pertumbuhan akar dan daun. Hormon yang terdapat di vermikompos antara lain auksin (3.80 ì̀geq $\left.\mathrm{g}^{-1} \mathrm{BK}\right)$, sitokinin (1.05 ìgeq $\left.\mathrm{g}^{-1} \mathrm{BK}\right)$, dan giberelin (2.75 ìgeq $\mathrm{g}^{-1} \mathrm{BK}$ (Mashur, 2001). Sitokinin dan auksin adalah hormon yang berperan dalam perkembangan akar (diferensiasi akar dan root gravitropism) serta bersama etilen mengatur inisiasi akar lateral (Aloni et al., 2005).

Tinggi Bibit (cm)

Tinggi bibit mentimun Daria paling besar diperoleh dari perlakuan media campuran vermikompos-arang sekam. Penggunaan vermikompos sebagai media transplant bibit mentimun kulivar Sultan F1 dan Storm F1 secara nyata $(\mathrm{P} \leq 0.05)$ meningkatkan tinggi batang pada 30, 60, dan 90 hari setelah transplant dengan semakin meningkatnya dosis vermikompos $(0,10$, 20, 30 ton ha ${ }^{-1}$ ) yang diberikan (Azarmi et al., 2009). Campuran arang

Tabel2. Daya berkecambah mentimun pada beberapa media pembibitan

\begin{tabular}{|c|c|}
\hline Media & Daya Berkecambah (\%) \\
\hline Vermikompos & $0.96875^{\mathrm{a}}$ \\
\hline Arang sekam & $0.93750^{\mathrm{a}}$ \\
\hline POG & $0.21875^{\mathrm{c}}$ \\
\hline Vermikompos : Arang sekam & $0.95313^{\mathrm{a}}$ \\
\hline Vermikompos:POG & $0.93750^{\mathrm{a}}$ \\
\hline Arang sekam:POG & $0.68750^{\mathrm{b}}$ \\
\hline Vermikompos: Arang sekam:POG & $0.92188^{\mathrm{a}}$ \\
\hline
\end{tabular}

Keterangan: Angka pada kolom yang sama yang diikuti oleh huruf yang berbeda menunjukkan berbeda nyata pada taraf $5 \%$ uji DMRT 
sekam dan kompos daun bambu juga meningkatkan tinggi mentimun Gherkin pada 6, 7, dan 8 minggu setelah tanam(Faruqi, 2011).

Komposisi media vermikompos-arang sekam memberikan hasil tinggi tanaman terbesar karena media tersebut memiliki sifat fisik dan kimia yang sesuai bagi pertubuhan mentimun (Gambar 1). Hal tersebut terlihat dari nilai bulk density $\left(0.32 \mathrm{~g} \mathrm{ml}^{-1}\right)$, total pore space $(98.378 \%), \mathrm{pH}(6.91)$, dan EC $\left(260 \mu \mathrm{S} \mathrm{cm}^{-1}\right)$. Komposisi hara vermikompos kotoran sapi juga lebih baik dibandingkan kotoran sapi yang digunakan sebagai pupuk dengan pengolahan konvensional. Komposisi hara vermikompos kotoran sapi adalah nitrat (259.4 ppm), amonium (141.5 ppm), fosfor (0.18 \% BK), kalium (0.41 $\%$ BK), kalsium ( $0.59 \%$ BK), dan magnesium ( $0.08 \%$ BK) (Suharyanto).

Sehingga dengan kecukupan hara pada media vermikompos ini, pertumbuhan bibit mentimun dapat optimal. Campuran vermikompos dengan arang sekam meningkatkan nilai total pore space media dibandingkan jika hanya menggunakan vermikompos saja (98.368\%). Arang sekam adalah media yang mudah didapat, ringan, steril, dan mempunyai porositas yang baik (BBPP Lembang, 2010). Sehingga pergerakan akar tanaman dalam penyerapan hara dan kemampuan menyimpan air media lebih baik.

\section{Jumlah (helai) dan Luas Daun $\left(\mathrm{cm}^{2}\right)$}

Jumlah daun mentimun tertinggi diperoleh dari komposisi media vermikompos-arang sekam, arang sekam, dan vermikompos. Sementara luas daun tertinggi diperoleh dari komposisi media vermikompos-arang sekam, arang sekam, vermikompos, vermikompos-pupuk organik granul, dan vermikompos-arang sekam-pupuk organik granul (Tabel 3). Dari kedua parameter pengamatan ini terlihat bahwa media tanam yang memberi kontribusi terbesar dalam pertumbuhan daun mentimun adalah vermikompos dan arang sekam. Penggunaan vermikompos sebagai media transplant bibit mentimun kulivar Sultan F1 dan Storm F1 secara nyata $(\mathrm{P} \leq 0.05)$ meningkatkan jumlah daun, luas daun, dan kandungan klorofil pada 30, 60, dan 90 hari setelah transplant dengan semakin meningkatnya dosis vermikompos (0, 10, 20, 30 ton $^{-1}{ }^{-1}$ ) yang diberikan (Azarmi et al., 2009). Vermikompos selain mengandung beragam unsur hara dan hormon yang mendukung pertumbuhan tanaman, juga mengandung beberapa mikroba tanah yang membantu penyediaan unsur hara tersedia bagi tanaman Vermikompos mengandung mikroba seperti Actinomycetes $\left(2.8 \times 10^{6} \mathrm{sel} \mathrm{g}^{-1}\right.$ $\mathrm{BK})$, bakteri (1.8 x $\left.10^{8} \mathrm{sel} \mathrm{g}^{-1} \mathrm{BK}\right)$, dan fungi (2.6 x $\left.10^{5} \mathrm{sel} \mathrm{g}^{-1} \mathrm{BK}\right)$. Bakteri Azotobacter sp. yang terdapat di vermikompos merupakan bakteri penambat $\mathrm{N}_{2}$ non simbiotik. Kandungan nitrogen pada vermikompos juga disebabkan oleh mineralisasi bahan organik cacing tanah yang telah mati dan ekskresi mukus dari tubuhnya yang kaya nitrogen (Mashur, 2001). Azotobacter sp. juga mengandung asam pantotenat (vitamin B5) yang berperan sebagai pembawa grup asil dalam siklus Krebs, sintesis lipid, asam lemak, gliserida, kolesterol, badan-badan keton (Suarsana).

Arang sekam selain mengandung karbon juga mengandung hara seperti fosfor dan kalium. Kandungan fosfor dan kalium total sekam padi masing-masing adalah 585 ppm dan 92 ppm dengan nilai kapasitas tukar kation 16.70 me/100 gr (Soemeinaboedhy dan Tejowulan, 2007). Nilai kapasitas tukar kation yang tinggi menandakan bahwa kemampuan bahan tersebut dalam pelepasan unsur hara juga tinggi.

\section{Pengamatan Panen Bibit Mentimun}

Hasil pengamatan pada karakter volume akar, panjang akar, bobot basah tajuk, bobot basah akar serta rasio tajuk akar menunjukkan bahwa perlakuan media pembibitan mentimun yang memberikan hasil terbaik adalah vermikompos, arang sekam, vermikompos-arang sekam, dan vermikompos-arang sekam-pupuk organik granul (Tabel 4). Penggunaan vermikompos sebagai media transplant bibit mentimun kulivar Sultan F1 dan Storm $\mathrm{F} 1$ secara nyata $(\mathrm{P} \leq 0.05)$ meningkatkan bobot kering batang, bobot kering daun, dan produksi pada 30, 60, dan 90 hari setelah transplant dengan semakin meningkatnya dosis vermikompos $\left(0,10,20,30\right.$ ton $\left.\mathrm{ha}^{-1}\right)$ yang diberikan (Azarmi et al., 2009).

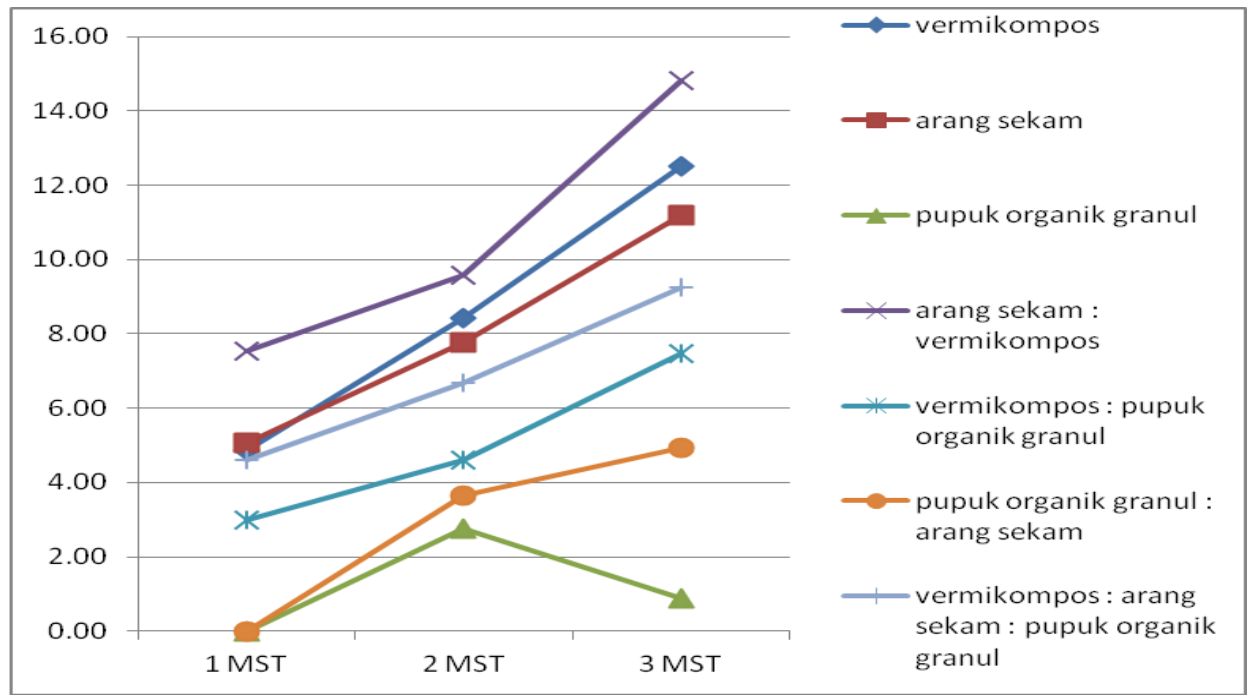

Gambar 1. Tinggi bibit mentimun (cm) pada beberapa media pembibitan 
Tabel3. Jumlah dan luas daun bibit mentimun pada beberapa media pembibitan

\begin{tabular}{lcc}
\hline \multicolumn{1}{c}{ Perlakuan Media } & Jumlah Daun & Luas Daun $\left(\mathrm{cm}^{2}\right)$ \\
\hline Vermikompos & $2.08^{\mathrm{ab}}$ & $9.23^{\mathrm{a}}$ \\
Arang sekam & $2.00^{\mathrm{ab}}$ & $9.31^{\mathrm{a}}$ \\
POG & $0.00^{\mathrm{d}}$ & $0.000^{\mathrm{b}}$ \\
Vermikompos : Arang sekam & $2.34^{\mathrm{a}}$ & $11.48^{\mathrm{a}}$ \\
Vermikompos : POG & $1.72^{\mathrm{b}}$ & $4.80^{\mathrm{ab}}$ \\
Arang sekam: POG & $0.75^{\mathrm{c}}$ & $1.96^{\mathrm{b}}$ \\
Vermikompos: Arang Sekam:POG & $1.86^{\mathrm{b}}$ & $6.54^{\mathrm{ab}}$
\end{tabular}

Keterangan: Angka pada kolom yang sama yang diikutioleh huruf yang berbeda menunjukkan berbeda nyata pada taraf $5 \%$ uji DMRT

Tabel4. Pengamatan panen bibit mentimun pada beberapa media pembibitan

\begin{tabular}{|c|c|c|c|c|c|}
\hline Perlakuan Media & $\begin{array}{l}\text { Volume Akar } \\
\text { (ml) }\end{array}$ & $\begin{array}{l}\text { Panjang Akar } \\
(\mathrm{cm})\end{array}$ & $\begin{array}{l}\text { Bobot Basah Tajuk } \\
\text { (g) }\end{array}$ & $\begin{array}{l}\text { Bobot Basah Akar } \\
\text { (g) }\end{array}$ & Rasio Tajuk Akar \\
\hline Vermikompos & $3.00^{\mathrm{ab}}$ & $8.41^{\mathrm{bc}}$ & $24.70^{\mathrm{a}}$ & $2.43^{\mathrm{a}}$ & $4.94^{\mathrm{a}}$ \\
\hline Arang sekam & $2.00^{\mathrm{bc}}$ & $9.50^{\mathrm{ab}}$ & $12.28^{\mathrm{bc}}$ & $1.37^{\mathrm{b}}$ & $3.76^{\mathrm{ab}}$ \\
\hline POG & $0.00^{\mathrm{e}}$ & $0.00^{\mathrm{e}}$ & $0.00^{\mathrm{d}}$ & $0.00^{\mathrm{d}}$ & - \\
\hline Arang sekam: Vermikompos & $3.5^{\mathrm{a}}$ & $10.61^{\mathrm{a}}$ & $25.16^{\mathrm{a}}$ & $2.43^{\mathrm{a}}$ & $5.07^{\mathrm{a}}$ \\
\hline Vermikompos: POG & $1.25^{\mathrm{dc}}$ & $6.95^{\mathrm{c}}$ & $2.04^{\mathrm{d}}$ & $1.07^{\mathrm{bc}}$ & $2.65^{\mathrm{bc}}$ \\
\hline Arang sekam:POG & $0.56^{\mathrm{de}}$ & $4.78^{\mathrm{d}}$ & $7.47^{\circ}$ & $0.23^{\mathrm{dd}}$ & $2.18^{\mathrm{c}}$ \\
\hline $\begin{array}{l}\text { Vermikompos : Arang sekam: } \\
\text { POG }\end{array}$ & $3.50^{\mathrm{a}}$ & $7.54^{\mathrm{c}}$ & $16.60^{\mathrm{b}}$ & $2.72^{\mathrm{a}}$ & $3.51^{\mathrm{bc}}$ \\
\hline
\end{tabular}

Keterangan: Angka pada kolom yang sama yang diikuti oleh huruf yang berbeda menunjukkan berbeda nyata pada taraf $5 \%$ uji DMRT

Vermikompos dan arang sekam merupakan dua jenis media yang memberikan hasil pertumbuhan bibit mentimun yang baik. Hal tersebut terlihat pada tingginya nilai karakter pengamatan panen bibit mentimun yang menggunakan media arang sekam atau vermikompos dalam komposisinya (Gambar 2). Arang sekam memiliki sifat fisik (bulk density rendah dan total pore space tinggi) serta sifat kimia (KTK tinggi) yang baik. Sehingga proses penyerapan hara berlangsung dengan optimal. Sementara vermikompos juga memiliki kemampuan menahan air yang tinggi dengan nilai total pore space $98.368 \%$. Mashur (2001) menyatakan bahwa kemampuan vermikompos dalam mengikat air dan unsur hara tanah dikarenakan adanya kesatuan agregat partikel vermikompos dengan adanya senyawa Ca-humat yang disekresikan oleh cacing.

Kemampuan penyediaan unsur hara, air, dan udara yang cukup pada media vermikompos dan arang sekam inilah yang membuat pertumbuhan bibit mentimun berlangsung optimal. Akar bibit mentimun mampu berkembang dengan optimal (volume dan panjang akar bernilai besar) sehingga serapan hara juga optimal. Serapan hara oleh akar juga akan mempengaruhi pertumbuhan tajuk. Pertumbuhan tajuk ikut meningkat seiring dengan meningkatnya pertumbuhan akar. Hal tersebut terlihat pada rasio tajuk akar yang tinggi. Rasio tajuk akar bibit mentimun yang ditanam di media vermikompos adalah 6.25 (Sallaku, 2009). Petumbuhan tajuk dan akar yang optimal akhirnya akan mempengaruhi bobot basah tajuk dan akar.

\section{KESIMPULAN}

Media tanam yang memberikan hasil terbaik pada pertumbuhan bibit mentimun adalah media kombinasi vermikompos-arang sekam. Media pupuk organik granul merupakan media tanam yang kurang optimal bagi 


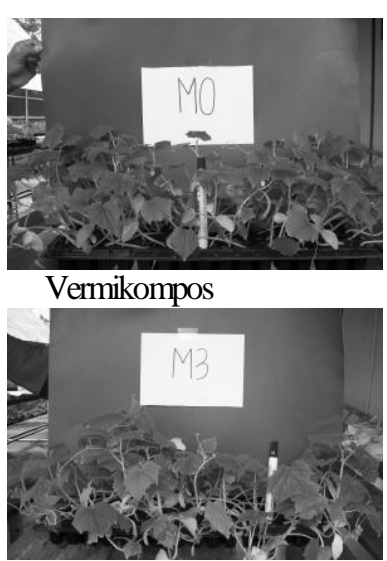

Vermikompos : Arang sekam

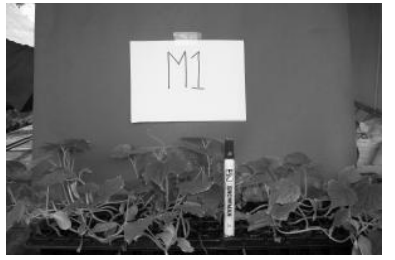

Arang sekam

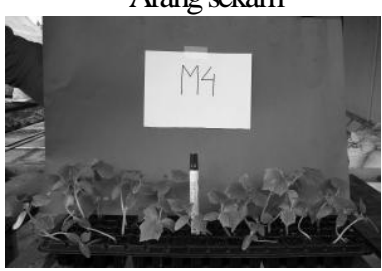

Vermikompos : POG

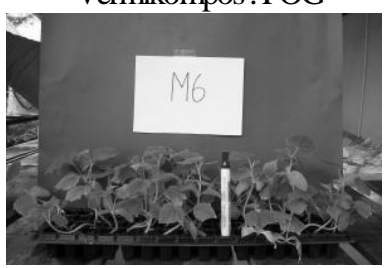

Vermikompos : Arang sekam:POG

Gambar 2. Keragaan bibit mentimun pada saat panen(3 MST)

pertumbuhan bibit mentimun. Hal ini mungkin disebabkan $\mathrm{pH}$ nya yang terlalu tinggi (8.68). Media pembibitan mentimun akan memberikan hasil pertumbuhan yang baik jika menggunakan vermikompos sebagai salah satu bahan penyusun media tanam.

\section{DAFTAR PUSTAKA}

AgrInfo. 2011. Density of soil: bulk density and particle density. http://www.agriinfo.in. [Diakses pada: 13 Juni 2012].

Aloni, R., E. Aloni, M. Langhans, C.I. Ullrich. 2005. Role of cytokinin and auxin in shaping root architecture: regulating vascular differentiation, lateral root initiation, root apical dominance and root gravitropism. Annals of Botany. 97(5): 883-893.

Azarmi, R., M.T. Giglou, B. Hajieghrari. 2009. The effect of sheep-manure vermicompost on quantitative and qualitative properties of cucumber (Cucumis sativus L.) grown in the greenhouse. African Journal of Biotechnology. 8(19): 4953-4957.

BBPP Lembang. 2010. Media tanaman hidroponik dari arang sekam. http://www2.bbpp-lembang.info. [14 Juni 2012].

Chulaka, P., T. Maruo, M. Takagaki, Y. shinohara. 2004. Organic substrates of tropical origin as an alternative to growing media for chilli and cucumber transplant production [abstract]. Japanese Journal of Tropical Agriculture. 48(2): 79-87.
Faruqi I. 2011. Pengaruh media tanam dan varietas terhadap pertumbuhan dan hasil tanaman Gherkin (Cucumis angularia L.) pada sistem hidroponik. http://repository.ipb.ac.id. [12 Juni 2012].

Mashur. 2001. Vermikompos (kompos cacing tanah) pupuk organik berkualitas dan ramah lingkungan. Tersedia pada: http://pustaka.litbang.deptan.go.id/agritek/ntbr0102.pdf. [diakses 12 Juni 2012].

Mirza, M., M. Younus. 2002. Some suggestion for vegetable transplants production. http://www1.agric.gov.ab.ca. [12 Juni 2012].

Mohiuddin, A.K.M., Z.C. Abdullah, M.K.U. Chowdhury, S. Napis. 2005. Enhancement of adventitious shoot regeneration Cucumis sativus L. using $\mathrm{AgNO}_{3}$. Plant Tissue Cult. 15(1):15-23.

Munir. 2011. Cara menanam mentimun. Tersedia pada: http://munir2011.student.umm.ac.id. [Diakses tanggal 12 Juni 2012].

Nair, A., M. Ngouajio M. 2012. Greenhouse transplant production tips. http://www.growingproduce.com. [Diakses tanggal 11 Juni 2012].

Roddy E. 2005. Cucumber production. http://www.omafra.gov.on.ca. [12 Juni 2012].

Sallaku G, Babaj I, Kaciu S, Balliu A. 2009. The influence of vermicompost on plant growth characteristics of cucumber (Cucumis sativus L.) 
seedling under saline conditions. Journal of Food, Agriculture and Environment. 7(3-4):869-872.

Santos BM. 2010. Transplant production. http://edis.fas.ufl.edu/cv104. [12 Juni 2012].

Soemeinaboedhy, I.N., R.S. Tejowulan. 2007. Pemanfaatan berbagai macam arang sebagai sumber unsur hara $P$ dan $K$ serta sebagai pembenah tanah. Agroteksos. 17(2):114-122.
Suarsana, I.N. 2012. Vitamin dan mineral. http://staff.unud.ac.id. [Diakses tanggal 14 Juni 2012].

Suharyanto. 2012. Vermikompos. Tersedia pada: http://www.scribd.com/mohammad_k_1/d/81010590-jadivermikompos. [Diakses tanggal 14 Juni 2012].

Susila, A.D. 2006. Panduan Budidaya Tanaman Sayuran. Bogor: Departemen Agronomi dan Hortikultura, Fakultas Pertanian IPB. 